Jurnal Ekonomi Pembangunan, 18 (2), 2017, 194-204

\title{
Earmarking Tax Optimization to Support The Effective and Sustainable Infrastructure
}

\begin{tabular}{|c|}
\hline Hadi Sasana \\
Faculty of Economics and Business, Diponegoro University, Indonesia \\
Corresponding Author: hadisasana@live.undip.ac.id \\
\hline
\end{tabular}

Received: May 2017 | Revised: November 2017 | Accepted: November 2017

\begin{abstract}
The majority of road infrastructure condition is far from excellent. The implementation of $10 \%$ minimum compulsory allocation of vehicle tax to be returned for road and transportation sector is potential to increase road maintenance fund.The research purpose is to raise regional revenue sources of Semarang City which is worth to be earmarked and to be alocated for road maintenance. This research is using secondary data of 2008-2015 period and linear regression analysis with Ordinary Least Square (OLS) method. The result of research concludes that : 1) the sources of earmarking consist of : vehicle tax (PKB), fee of vehicle title transfer (BBNKB), and fuel tax (PPBKB). 2) the allocation proportion of each earmarking source for Semarang City road maintenancefor next five years are : $25 \%(\mathrm{PKB}), 15 \%$ (BBKNB), and 15\% (PBBKB). 3) the allocation proportion of each earmarking source for Semarang City roadconstruction for next five years are: 50\% (PKB), 45\% (BBNKB), and 45\% (PBBKB).
\end{abstract}

Keywords: Earmarking tax, Vehicle tax, Fee of vehicle title transfer, Fuel tax JEL Classification: H71, H25, H26, H41

How to cite: Sasana, H.(2017). Earmarking Tax Optimization to Support The Effective and Sustainable Infrastructure. Jurnal Ekonomi Pembangunan: Kajian Masalah Ekonomi dan Pembangunan, 18(2), 53-63. doi:https://doi.org/10.23917/jep.v18i2.4168

DOI: https://doi.org/10.23917/jep.v18i2.4168

\section{Introduction}

Semarang City as metropolitan city with primary activity in trading and service sector needs an adequate physical infrastructure. Semarang is located in the middle of distribution route of West-East Java, which in one hand has strategic advantage. On the other hand, has high responsibility as it has to keep or to improve its role and function as the support of national economic distribution route as well as internal accesibility which has function as regional economy prime mover. Infrastructure, especially road, is considered inadequate. Road length in all Semarang regions reach 2,762.261 $\mathrm{Km}$. Based on the the type of the surface, only $52.12 \%$ which is coated by asphalt. While, based on condition, only $44.87 \%$ in the good condition; the rest is the moderate and damaged condition ( BPS Semarang City, 2015). Road sector is not a priority to be funded, it can be seen from budgetallocation for road and bridge sector which areless than $10 \%$ of total expenditure in 20092014 period (APBD Semarang City, 2015). The amount of fund is far from enough to meet the need of road control program which consists of maintenance, improvement, and construction. Road maintenance is the responsibility of government as public servant. Apart from routine responsibility on direct expenditure component, the responsibility of road maintenance is emphazed as well on Act No. 22 of 2009 about traffic and trasnportation regulation which 


\section{Jurnal Ekonomi Pembangunan, 18 (2), 2017, 194-204}

states that damaged road renovation is urgent to be implemented by road operator due to traffic accident. According to World Road Association (2015) "Funding refers to how the road is finally paid for, while financing refers to how to raise funds to pay for an infrastructure. Thus, funding answers to the question "where the money for the concession ultimately comes from" and financing answers to "where investment (or other cash necessities) comes from".

The necessity of road renovation will not meet the expectation without being supported by binding rule, Act No. 28 of 2009 about Regional Tax and Regional Retribution is a starting point of the awareness of central government about the importance of road sector concern which is deteriorating in the regional level. Meanwhile, the road load is dramatically increasing and uncontrollable. The law regulates a new tax system in Indonesia: a progressive tax and earmarking tax. It states that minimum $10 \%$ of vehicle tax revenue must be allocated to transportation sector including road maintenance. This is one of potential strategies to improve road maintenance fund. Barrett and Greene (2013), stated the road financing as an effort to to improve the benefit which can be experienced directly by taxpayer in the particular treatment such as repairing potholes and reducing road accidents.

Local Revenue is a part of local earnings which is raised from several sources : locallygenerated revenue, balancing fund, and others.
Based on the source, the revenue of local activity is grouped as local original revenue (PAD). The revenue of transfer from central government to province government including grants are grouped as balancing fund and other local revenue. According to Brodjonegoro (2015), who quoted Act No.25 of 1999 about local tax sources as revenue sharing, general allocation fund, and spesific allocation fund. Furthermore, he also mentioned that revenue sharing could be classified into natural resource revenue and tax revenue sharing. However, local government will only receive less if tax revenue compared to central government. Siahaan (2010) argues that local tax is kind of tax which is authorised by local government by local regulation. The raising proccess is conducted by local government and the result is supposed to finance government operations and development in the regional level. These are types of tax (Table 1).

Regarding the types of tax related to road infrastructure, province government handles dominant authority of them, such as vehicle tax (PKB), vehicle title transfer fee (BBKNB), and fuel tax (PBBKB). Taxes related to road infrastructure are received by city/district goverment through profit sharing system. The system instruction for profit sharing is based on Act No.28 of 2009 : the revenue of $\mathrm{PKB}$ is $30 \%$ transfered to district/ city government; 30\% from BBNKB; $70 \%$ from PBBKB.Regarding to mandate of Act No. 28 of 2009, source of local revenue that should be

Table 1. Types of Province Tax and District/City Tax

\begin{tabular}{ll}
\hline \multicolumn{1}{c}{ Local tax (Province Level) } & \multicolumn{1}{c}{ Local Tax (City and District Level) } \\
\hline & a. Hotel Tax \\
& b. Restaurant Tax \\
a. Vehicle Tax & c. Entertainment Tax \\
b. Vehicle Trasnfer Title Tittle & d. Advertisment Tax \\
c. Fuel Tax & e. Street Lighting Tax \\
d. Water Surface Tax & f. Non-metal and Rock Mineral Tax \\
e. Tobacco Tax & g. Parking Tax \\
& h. Underground Water Tax \\
& i. City Rural Land and Building Tax \\
& j. Swift's Nest Tax \\
\hline
\end{tabular}

Source : Act No.28 of 2009 


\section{Jurnal Ekonomi Pembangunan, 18 (2), 2017, 194-204}

earmarked to be road maintenance allocation is vehicle tax. At least $10 \%$ of revenue is alocated to road construction and mainteanance and to improve public trasportation mode and infrastructure.

Carling (2007) tax earmarking means something different for different people. In a specific form it is income from a certain tax separated from general income, and can only be used for certain government programs of that fund. Tax allocations are separated for specific purposes and inflexible for their use as determined in the budget. All revenue from particular tax from general revenue could only be used for spesific and special government programs.In addition, that in the term of financial aspect, earmarking refers to allocation or revenue flows of spesific individuals or operations, and in the actual condition, there is an intersection between central government regulation about tax, non-taxable organizations and donors as well. Tifany (2015), stated that usually, there issome levels associated to tax revenue sources with funded programs or activities, for example environment tax which is used to fund environment conservation activities, oil tax which can be used to fund road renovation and maintenance, and other.There are also constraints from the government budgeting perspective. The earmarking practice may deprive policymakers of the flexibility to effectively allocate funds among different expenditure programmes based on the prevalent needs. The government may simply take the earmark as the appropriate level of spending for the programme and need not compare it against other competing claims. Assessing all competing claims to determine which of them will provide the most public benefits for the money spent is generally considered to be good budgeting practice. However, for earmarking, the government may simply adopt the earmarked level of spending. Hence, there are critics that earmarking introduces rigidities, making budgetary planning and control difficult while incurring additional administrative costs arising from separate tracking and accounting.
Michael (2015) stated that earmarking is designed to be dedicative practice of tax allocation or other revenues to particular program or goals. This practice sets a special account for depositing tax and other revenue to be utilized furher for designated purpose. Eamarking is supposed to be a public service quality enhancement which has ability to sustain, and generating good governance and clean government (Siahaan, 2010 ).Earmarking tax based on the source is divided into two : full earmark and partial earmark. Full earmark is all revenues which are allocated to fund whole program completely, while partial earmark is an allocation for program funding not only from earmark revenue but also other costs which are authorized by legislative board (Michael, 2015).

According to Antameng (2008), earmarking for road budget is alocated for road sector. This earmarking is able to determine the amount of road revenue which can be alocated for road. According to Smith (1975) earmarking, tax for particular types of tax, is able to increase the revenue. Alternative to increase revenue from earmarked sources will encourage resource allocation to be more efficient. Likewise, utilizing revenue resources related to road will be more efficient if it is allocated to road sector. Based on the experience of earmarking implementation in several cities in developing countries, earmarking is able to help providing effective and sustainable minimum service standard particularly in fastgrowing cities. (Smith, 1975).

Earmarking is the first generation of road budget which was developed in the end of 1980 and in the begining of 1990(Potter, 2005). At that time, the volume and road maintenance quality was ineadequate in developing countries. The road condition was deteriorating as the result of budget pressure. It is easier to receive budget for constructing new roads (for example from donors) than raising budget for maintaining the existing roads. The first generation of road budget through earmarking was an effort to maintain roads from general effect of budget pressure (Potter, 
Jurnal Ekonomi Pembangunan, 18 (2), 2017, 194-204

2005).Gwilliam and Zmarak (1997) stated that second generation road funds are financed from retribution or surcharges authorized as user charge and separated from general taxation.

Based on theory and research gap, this research aims to: a) identification of earmarking revenue sources in Semarang City; b) setting the model of source allocation number for road maintenance and road construction in Semarang City, Central Java.

\section{REsearch Methodology}

This research is conducted in Semarang City as it has huge potential of earmarking tax, and as one of metropolitan cities. Semarang City is a primary distribution route connecting West Java and East Java. Furthermore, the city is a internal accesibility which has function as local economic prime mover.

Secondary data is used in this research and obtained from local finance and assets management board (DPKAD), Statistic Indonesia, Public Works Service (PU), and related institutions. Research period is between 2008 - 2015. Direct interview to related stakeholders as a primary data is used to complete the argumentation.The data is analyzed by quantitative linear regression with Ordinary Least Square (OLS) method. The linear regression model is as below :

$\mathrm{Y}_{1}=\mathrm{a}+B_{1} \mathrm{X}+\mathrm{u}_{\mathrm{t}}$

$\mathrm{Y}_{2}=\mathrm{a}+\mathrm{B}_{2} \mathrm{X}+\mathrm{u}_{\mathrm{t}}$

$\mathrm{Y}_{3}=\alpha+B_{3} \mathrm{X}+\mathrm{u}$

Note:

$\mathrm{Y}_{1}$ is tax vehicle; $\mathrm{Y}_{2}$ is vehicle title transfer fee; $\mathrm{Y}_{3}$ is fuel tax; $\mathrm{X}$ is year; $\alpha$ is intercept; $B$ is coeficient variable value; $u$ is error term.

Data analysis is done by conducting qualitative and quantitative approach. Qualitative is done descriptively from empirical data, while quantitative is using linear regression analysis.

\section{Result and Discussion}

\subsection{Construction and Maintenance Budget Of Semarang City Roads}

Road management program is divided into several categories which are maintenance, enhancement, and construction of new road. Semarang City government has several management programs including construction of new road such as setting outer ring road as well other city roads. During five years observation (2008 -2015), road construction project in particular spots in Semarang City showed significant progress of development.

The realization of road construction fund in Semarang City is far from the required allocation. The connection between construction budget and road maintenance in Semarang City is simultaneous. Empirical data show that the requiredroad budget and fund allocation is imbalance. The realization of road budget is fewer than the required allocation (See Figure 1).
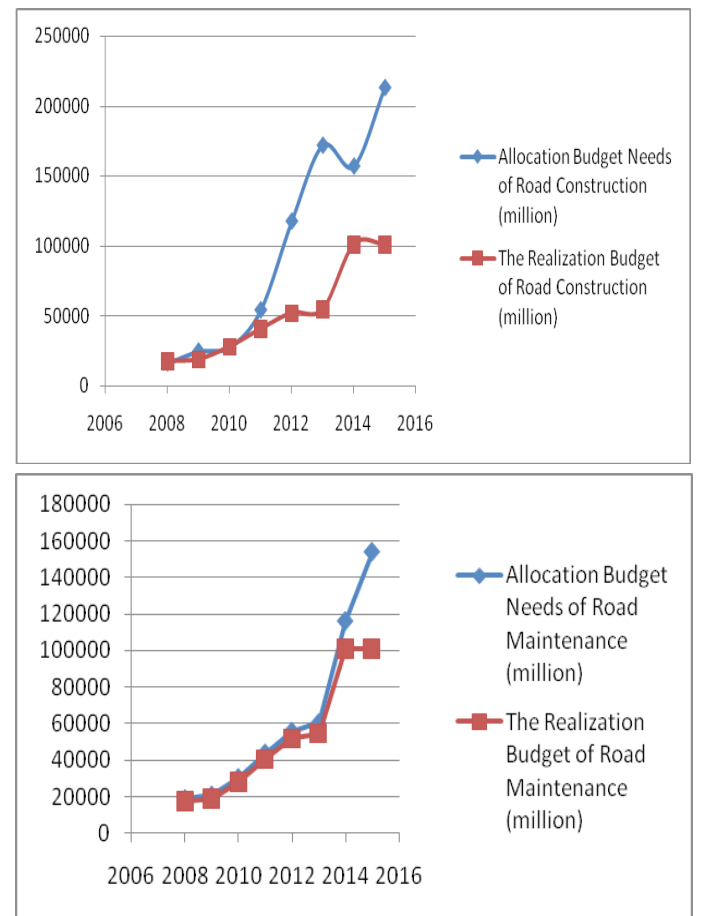

Source : Bina Marga Service Semarang City, 20082015 (proccessed)

Figure 1. Allocation needs, and The Realization of Road Construction and Maintenance in

Semarang City 2008 - 2015 (in million Rupiah) 
Jurnal Ekonomi Pembangunan, 18 (2), 2017, 194-204

The imbalance of allocation needs and budget realization is an impact of limited priority of Semarang City government's budget. Accordingto Seely (2011) consumption fuel limitting by goveernment will cause reducing of road renovation and maintenance expenditure because of reducing tax revenue.

\subsection{EArmarking Sources in Semarang City.}

The identiciation of local tax sources is Semarang City which can be earmarked according to regulation and fiscal capacity are (Surbakti, 2011) :

a. Type of revenue in the local government budget (APBD) component

Type of local revenue which is possible to be the earmarking source is the sources that include in the component of Semarang Citygovernment budget, which are local original revenue, balancing budget, and others.

b. Revenues base as the right of Semarang City government

According the purpose, road maintenance fund is allocated for city's road. Hence, the earmarked road maintenance fund comes from local original fund which is the rights of Semarang City. c. Potential source of revenue from land transportation sector

According to local fiscal capacity, it is possible to raise earmarking tax from existing sources, and does not always have direct connection to related sector. However, due to the limited fiscal capacity, earmarking tax sourced from land transporation sector which related to road. The non-earmarked sources must have potential value for the necessity of road maintenance.

Based on empirical data and earmarking sources identification, there are three types of local revenue sources in Semarang City which are possible to be earmarked. Earmarked sources are : Vehicle Tax, Vehicle title transfer free, and fuel tax. Brodjonegoro (2015) stated about local tax revenue: Indonesia local governments still have a weak local taxing power. The bigger part of total revenue, coming from income tax revenue and value added tax revenue, are still dominated by the central government. At the provincial level only two types of local taxes could be considered significant to total local revenue, namenly car registration tax and car ownership transfer tax. According to Brodjonegoro, the most significant local government revenue is from vehicle tac and vehicle title transfer fee.

\subsection{REVENUE OF EARMARKING SOURCES}

Figure 2. The increase of vehicle tax, Vehicle title transfer free, and fuel tax in Semarang City 2008 - 2015 (in Million Rupiah)

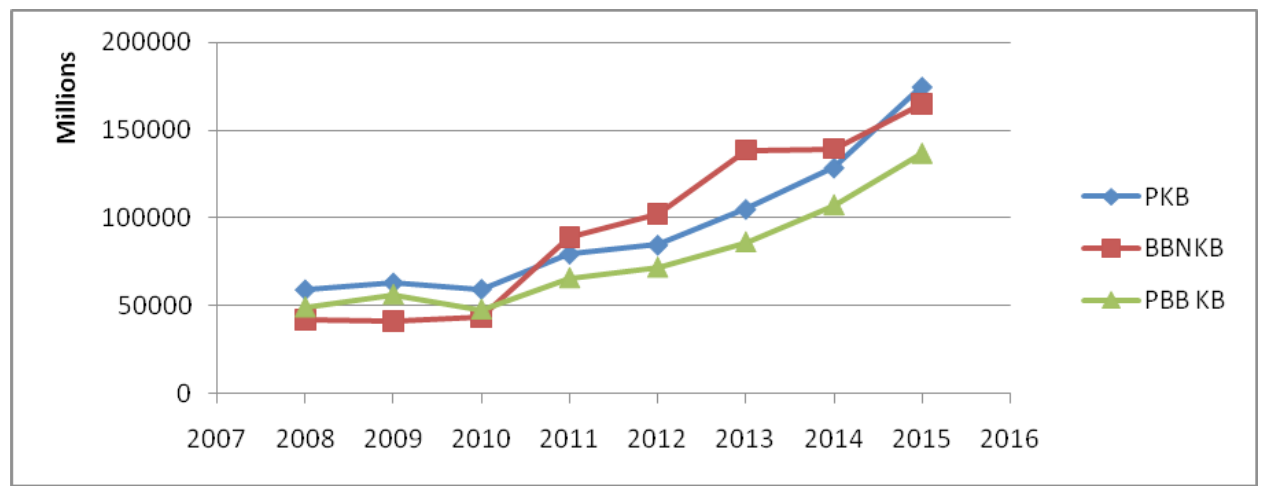

Source : BPS Semarang City, 2008-2016 (proccessed) 
Jurnal Ekonomi Pembangunan, 18 (2), 2017, 194-204

Vehicle tax, vehicle title transfer fee, and fuel tax are local tax with the province government as the raising authority. That local tax has fundamental legal base which are; Act No.28 of 2009; Government Regulation No.56 of 2001 about local tax; local regulation about vehicle tax, Regulation of ministry of internal affairs No. 2 of 2006 about calculation of tax base for vehicle tax and vehicle title transfrer fee. Those tax revenues was incresing at $2008-2015$ period in Semarang City as shown in Figure 2.

It can be clearly seen from empirical data in Figure 2 that revenue of vehicle tax, Vehicle title transfer free, and fuel tax in Semarang City show an increase from 2008 -2015. This is a result of the increase of vehicle, and the increase of income per capita in Semarang City.Earmarking Tax will be much better on stable economic condition, when tax revenue is predictable and stable, moreover expnediture for program is predictable as well (Kavale,
2014).

\subsection{Total Allocation Analysis and Earmarking Sources Forecasting 3.4.1 Maintance Construction Budget Needs}

The counstruction of city infrastructure such construction of roads, bridge, drainage system and environtment renovation has become important concern of Semarang City government. Budget needs for infrastucture especially for road is increasing every year. Based on the last historical data, road maintenance and construction budget estimation is as shown below.

Estimation results show that road maintenance and construction budget can be expalined by the time/year progression. As a long term consequence of road renovation and maintenance delay is not only increasing total cost, but also cashflow value will be more significantly high in the future (Gwilliam and Zmarak, 1997) .Later the year, bigger the

Table 2. Budget Estimation for Road Maintenance in Semarang City

\begin{tabular}{cccc}
\hline Variable & Coefficient & t-Statistic & Prob. \\
\hline Year & $1.29 \mathrm{E}+10$ & 7.362147 & 0.0003 \\
C & $-2.60 \mathrm{E}+13$ & -7.347525 & 0.0003 \\
R Squared & 0.900334 & & \\
F Statistic & 54.20120 & & \\
\hline
\end{tabular}

Table 3. Budget Estimation for Road Construction in Semarang City

\begin{tabular}{cccc}
\hline Variable & Coefficient & t-Statistic & Prob. \\
\hline Year & $2.42 \mathrm{E}+10$ & 9.559187 & 0.0001 \\
C & $-4.85 \mathrm{E}+13$ & -9.543995 & 0.0001 \\
R Squared & 0.938384 & & \\
F Statistic & 91.378080 & & \\
\hline
\end{tabular}

Tabel 4. The Estimation of Road Maintenance and Construction in Semarang City2016 - 2020

\begin{tabular}{cccccc}
\hline Year & $\begin{array}{c}\text { Maintenance } \\
\text { need (Million } \\
\mathbf{R p})\end{array}$ & $\begin{array}{c}\text { Increase } \\
\text { percentage }\end{array}$ & $\begin{array}{c}\text { Construction } \\
\text { need (million } \\
\text { Rp) }\end{array}$ & $\begin{array}{c}\text { Increase } \\
\text { percentage }\end{array}$ & $\begin{array}{c}\text { Maintenance and } \\
\text { Construction } \\
\text { need (Million Rp) }\end{array}$ \\
\hline 2016 & 113.820 & - & 187.138 & - & 300.958 \\
2017 & 126.720 & 0,11 & 211.338 & 0,13 & 338.058 \\
2018 & 139.620 & 0,10 & 235.538 & 0,12 & 375.158 \\
2019 & 152.520 & 0,09 & 259.738 & 0,10 & 412.258 \\
2020 & 165.420 & 0,08 & 283.938 & 0,09 & 449.358 \\
& Average & 0,095 & & 0,10 & \\
\hline
\end{tabular}


budget needs. Furhermore, based on estimation result, the estimation of road maintenance and construction in Semarang City is as mentioned above.

Budget needs for infrastucture especially for road was increasing every year in 2016 2020 period. The average increase percentage for maintenance per year is $9.5 \%$. The average increase percentage for construction per year is higher at $11 \%$. According to Asian Development Bank (2003), road renovation finance is associated to weather and time, annual increasing vehicle quantity means higher cost because of increasing of road load.

\subsubsection{FORECASTING OF EARMARKING REVENUE SOURCES IN SEMARANG CITY}

The earmarking revenue sources in Semarang City were increasing along with an increase of total vehicle and income per capita. Based on historical data, estimation result of vehicle tax revenue in Semarang City is as shown below :
Based on estimation result, 92.38 percent of vehicle tax can be explained by time/year progression. While, 7.62 percent is explained by other external variables. According to Baxandall (2011), earmarking tax revenue source is not only from tax but also from other charges. Furthermore, estimation result of vehicle title transfer fee revenue will be shown below.

Estimation result shows 94.10 percent of vehicle title tranfer tax can be explained by time/year progression. While, 5.90 percent is explained by other external variables. Estimation result of fule tax revenue will be shown below.

Estimation result shows 85.98 percent of fuel tax revenue can be explained by time/year progression. The result is in line with previous research by Surbakti (2011) in forecasting of earmarking sources from local revenue in Bandung City. The prediction of vehicle tax, vehicle title transfer fee, and fuel tax revenue for next five years can be seen in the Table 8 .

Table 5. Estimation Result of Vehicle Tax Revenue in Semarang City

\begin{tabular}{ccccc}
\hline Variable & Coefficient & Std.Eror & t-Statistic & Prob. \\
\hline Year & $1.52 \mathrm{E}+10$ & $2.65 \mathrm{E}+09$ & 5.744923 & 0.0012 \\
C & $-3.05 \mathrm{E}+13$ & $5.33 \mathrm{E}+12$ & -5.727210 & 0.0012 \\
R Squared & 0.923872 & & & \\
F Statistic & 72.81496 & & & \\
\hline
\end{tabular}

Table 6. Estimation Result of Vehicle Title Transfer Fee Tax Revenue in Semarang City

\begin{tabular}{ccccc}
\hline Variable & Coefficient & Std.Eror & t-Statistic & Prob. \\
\hline Year & $1.97 \mathrm{E}+10$ & $2.01 \mathrm{E}+09$ & 9.790503 & 0.0001 \\
C & $-3.95 \mathrm{E}+13$ & $4.04 \mathrm{E}+12$ & -9.766986 & 0.0001 \\
R Squared & 0.941092 & & & \\
F Statistic & 95.85395 & & & \\
\hline
\end{tabular}

Table 7. Estimation Result of Fuel Tax Revenue in Semarang City

\begin{tabular}{ccccc}
\hline Variable & Coefficient & Std.Eror & t-Statistic & Prob. \\
\hline Year & $1.18 \mathrm{E}+10$ & $1.94 \mathrm{E}+09$ & 6.067605 & 0.0009 \\
C & $-2.36 \mathrm{E}+13$ & $3.91 \mathrm{E}+12$ & -6.047771 & 0.0009 \\
R Squared & 0.859865 & & & \\
F Statistic & 36.81583 & & & \\
\hline
\end{tabular}


Jurnal Ekonomi Pembangunan, 18 (2), 2017, 194-204

Table 8. The forecast of Vehicle Tax, Vehicle Title Transfer Fee, And Fuel Tax Revenuein 2016 - 2020

\begin{tabular}{ccccccc}
\hline Year & $\begin{array}{c}\text { PKB } \\
\text { (million Rp) }\end{array}$ & $\begin{array}{c}\text { Increase } \\
\text { percentage }\end{array}$ & $\begin{array}{c}\text { BBNKB } \\
\text { (million Rp) }\end{array}$ & $\begin{array}{c}\text { Increase } \\
\text { percentage }\end{array}$ & $\begin{array}{c}\text { PBBKB } \\
\text { (million Rp) }\end{array}$ & $\begin{array}{c}\text { Increase } \\
\text { percentage }\end{array}$ \\
\hline 2016 & 189.977 & & 184.710 & & 212.271 & \\
2017 & 205.177 & 0.08 & 204.410 & 0.11 & 308.671 & 0.08 \\
2018 & 220.377 & 0.07 & 224.110 & 0.10 & 405.071 & 0.07 \\
2019 & 235.577 & 0.07 & 243.810 & 0.09 & 501.471 & 0.07 \\
2020 & 250.777 & 0.06 & 263.510 & 0.08 & 597.871 & 0.06 \\
\multicolumn{2}{c}{ Average } & 0.07 & & 0.095 & & 0.07 \\
\hline
\end{tabular}

The estimation result shows vehicle tax revenue will be increasing annually. The average precentage of increase for vehicle tax in Semarang City is 7 percent annually. The result also shows an increase for vehicle title transfer fee, and fuel tax revenue in the period of 2016 -2020 . The average precentage of increase for vehicle title transfer fee in Semarang City is 9.5 percent annually, and for fuel tax is 7 percent annually. The increase of vehicle tax, vehicle title transfer fee, and fuel tax revenue is caused by an increase in vehicle ownership by citizen of Semarang City, and by the increase of income per capita as well.Regulation and strategy to reduce tax avoidance behaviour can encourage relation of tax and public expenditure, earmarking tax ia beneficial strategy to improve tax revenue (Kavale, 2014).

\subsubsection{SCENARIO OF ALLOCATION FOR EARMARKING SOURCE \\ TOTAL EACH}

Based on forecasting result for each local earmarking source revenue, to identify the budget needs for road maintenance and construction as the purpose of earmarking tax for the next five years can be done by simulation. vehicle tax, vehicle title transfer fee, and fuel tax as the sources of earmarking tax are simulated the total of budget allocation to the budget needs for road maintenance and construction. Allocation for each earmarking source is legally based on earmarking tax within Act No.28 of 2009, which is a minimum allocation $10 \%$ from vehicle tax is for road maintenance. According toWilkinson (1994), transparant tax must ne earmarked because the pricincipal concept of earmarking is benefit and public choice approach to fund public goods through tax they paid.

However, due to the high budget needs to be allocated fo road maintenance and construction, $10 \%$ budget allocation from vehicle tax does not fulfil the budget needs of total Semarang City road maintenance budget. Therefore, it is necessary to raise other earmarking sources (vehicle title transfer fee, and fuel tax). Additional allocation sources are sorted based priority : vehicle tax, followed by vehicle title transfer fee, and fuel tax until it reaches a composition which can fulfil the estimation of road maintenance and construction budget. The scenario of additional two tax allocations for road maintenance and construction is done by two altenatives. Scenario I, budget allocation is based on the estimation of budget needs for related years, and Scenario II considers the impact of annual inflation average for $10 \%$. Simulation result of vehicle tax, vehicle title transfer fee, and fuel tax for road maintenance in Semarang City for 2016 - 2020 as mentioned in Table 9. 
Jurnal Ekonomi Pembangunan, 18 (2), 2017, 194-204

Table 9. Allocation Scenario of Vehicle Tax, Vehicle Title Transfer Fee, and Fuel Tax For Road Maintenance in Semarang City for 2016 - 2020

\begin{tabular}{cccc}
\hline Road Maintenance Budget Need & PKB (\%) & BBNKB (\%) & PBBKB (\%) \\
\hline a. Scenario I & 25 & 15 & 15 \\
b. Scemario II & 25 & 17 & 17 \\
\hline
\end{tabular}

Table 10. Scenario of Vehicle Tax (PKB), Vehicle Title Transfer Fee (BBNKB), and Fuel Tax (PBBKB) allocation for road maintenance and construction budget in Semarang City for $2016-2020$

\begin{tabular}{cccc}
\hline Road Maintenance Budget Need & PKB(\%) & BBNKB (\%) & PBBKB (\%) \\
\hline a. Scenario I & 50 & 45 & 45 \\
b. Scemario II & 55 & 50 & 50 \\
\hline
\end{tabular}

The composition of allocation for each earmarking source for road maintenance is not similar. Allocation from vehicle tax is higher than other two sources because vehicle tax is already assigned as the legal earmarking source by $10 \%$ minimum allocation. By the minimum allocation without maximum allocation, then the proportion of allocation still can be expanded. While, for vehicle title trasfer fee and fuel tax, both are allocated for each proportion 15\% (scenario I) and 17\% (scenario II). Both allocation are less than fifth of total revenue, and have relation with road sector which are feasible to be raised as Semarang City road maintenance. As a result, road maintenance budget needs can be fulfiled until 2020. The residual of earmarking sources from vehicle title trasnfer fee and fuel tax, $85 \%$ for Scenario I and $82 \%$ for Scenario, is enough and can be included in the revenue post in local govenment budget (APBD) for financing expenditures in other sectors. According to Antameng (2008), earmarking for road budget is supposed to be allocated for road sector, and this budget is still relevant to the roads condition in regional level which are majority in bad condition.According to Asian Development Bank (2003), road renovation and maintenance funding is included in capital expenditure because of the high cost and long term progression, so it needs special attention to manage the fund.

Budget realisation for road construction is increasing gradually,and higher than maintenance cost. Simulation of earmarking sources allocation for road maintenance and consctruction with priority order vehicle tax (PKB), followed by vehicle title transfer fee (BBNKB), and fuel tax (PBBKB) until it reaches the composition that can equalize the road maintenance and construction cost as mentioned in Table 10.

Semarang city road maintenance and construction needs tend to increase gradually, with allocation scenario as what mentioned in Table 10 budgeting needs will be fulfilled until 2020. Allocation from vehicle tax is still higher than other two sources. While, for Vehicle Title Transfer Fee (BBNKB), and Fuel Tax (PBBKB) are allocated with each allocation $45 \%$ for Scenario I and $50 \%$ for Scenario II. The percentages are still worth to be implemented due to maximum $50 \%$ of revenue from both total tax revenues. Besides, both tax sources are directly related to road sector, it is possible to be allocated for road maintenance and construction. The residual of sources revenue, which is $50 \%$, can be returned to local government budget for financing other sectors. Strong commitment from local government is necessary as a good intention to provide proper quality of public service. Potter (2005) stated that road funds through earmarking is an effort to maintain the road form broader budget pressure. According to CEDR (2017), it is necessary to afford balance in infrastructure renovation cost with revenue from road utilization in order to bring generate bigger benefit of road financing. 


\section{Conclusion}

Based in analysis result and identification of local earmarking sources,and budget needs for road maintenance in Semarang City can be concluded that:

a. Earmarking local revenue sources based on fiscal capacity, fiscal need, and Regulation criteria consist of : Vehicle Tax (PKB), Vehicle Title Transfer (BBNKB), and Fuel Tax (PBBKB).

b. The allocation for each earmarking source for road maintenance fo next five years are : 25\% for vehicle Tax (PKB), 15\% for Vehicle Title Transfer Fee (BBNKB), 15\% Fuel Tax (PBBKB) (Scenario I). The allocation for each earmarking source are $25 \%$ for vehicle Tax (PKB), 17\% for Vehicle Title Transfer Fee (BBNKB), 17\% Fuel Tax (PBBKB) (Scenario II).

c. The allocation for each earmarking source for road maintenance and construction fo next five years are : $50 \%$ for vehicle Tax (PKB), $45 \%$ for Vehicle Title Transfer Fee (BBNKB), 45\% Fuel Tax (PBBKB) (Scenario I). The allocation for each earmarking source are $55 \%$ for vehicle Tax (PKB), 50\% for Vehicle Title Transfer Fee (BBNKB), 50\% Fuel Tax (PBBKB) (Scenario II).

If Semarang City government wants to implement earmarking for financing road maintenance and construction :

a. Intensification through data update for identifying vehicle ownership and by striding people awareness to pay $\mathrm{PKB}, \mathrm{BBNKB}$, and $\mathrm{PBBKB}$ to increase earmarking revenue sources are necessary.

b. It is necessary to set strong fundamental legal protection in the implementation of earmarking system.

3. Law enforcement is important in orded to have succesful implementation of earmarking system

\section{Acknowledgments}

We would like to deliver our appreciation to Faculty of Economics and Business Diponegoro University for funding this research, and respondents who assisted the researcher.

\section{References}

Act No. 28 of 2009 about Regional Tax and Regional Retribution

Antameng, Max. (2008),"Progres Reformasi Manajemen Pemeliharaan Jalan MelaluiRoad Maintenance Fund di Indonesia”.Makalah Teknik KRTJ ke X (KRTJ 10), July 21, Jakarta, Indonesia

Asian Development Bank,(2003), "Roads Funds and Road Maintenance: An Asian Perspective". Asian Development Bank (ADB). https://www.adb.org/sites/default/ files/publication/160620/road-funds-androad-maintenance.pdf

Barrett, Katherine, and Richard Greene,(2013), "Is Earmarking the Best Way to Fund Projects?". http://www.governing.com/ columns/smart-mgmt/col-earmarking-bestfunding.html. Diakses 10 Mei 2017.

Baxandall, Phineas, (2011) "Do Roads Pay for Themselve? Setting the Record Straight on Transportationfunding". U.S PIRG Education Fund. http://www.uspirg.org/ reports/usp/do-roads-pay-themselves

BPS-Statistics of Semarang Municipality.2016. "Semarang Municipality in Figures". BPSStatistics of Semarang Municipality.2016. https://semarangkota.bps.go.id/website/ pdf_publikasi/Kota\%20Semarang\%20 dlm\%20Angka\%202016-wm.pdf

BPS-Statistics of Semarang Municipality.2015. "Semarang Municipality in Figures". BPSStatistics of Semarang Municipality.2015. https://semarangkota.bps.go.id/website/ pdf_publikasi/Kota\%20Semarang\%20 
Jurnal Ekonomi Pembangunan, 18 (2), 2017, 194-204

dlm\%20Angka\%202015-wm.pdf

Brodjonegoro,

Bambang,(2015),"Fiscal

Decentralization in Indonesia", The Institute of Economics and Social Reseach and The Graduate Program of Economics, University of Indonesia.

Carling, Robert,(2007), “ Tax Earmarking is It Good Practice?". The Center for Independent Studies, Perspectives on Tax Reform (12). www.cis.org.au/app/ uploads/2015/07/pm75.pdf

CEDR. (2017), "Funding Formulas for Roads: Inventory and Assessment".CEDR's Secretariat General. CEDR Technical report 2017/04. www.cedr.eu/.../TR2017-04Funding-formulas-for-roads.pdf

Dinas Binamarga Kota Semarang http:// pedestrian.binamarga.semarangkota.go.id/ index.php

Gwilliam, Kenneth M., and Zmarak M. Shalazi,(1997), "Road Funds, User Charges and Taxes". Discussion TWU Development, Paper of Work Bank.www.rhd.gov.bd/ Documents/ExternalPublications/.../B23. pdf

Kavale, Lucija. (2014), "Earmarking of Taxes: Economy or Policy?". Journal of Economic AnnalsVol. XXI.Pages 56-59.

Michael, Joel. (2015), "Earmarking State Tax Revenue". Policy Brief Research. Departement Minnesota House of Representatives.: St. Paul.www.house.leg. state.mn.us/hrd/pubs/earmarking.pdf

Potter, Barry H. (2005), Budgeting For Road Maintenance. Paper presented at the Report of The One Hundred and Thirty Fifth Round Table on Transport Economics.
Seely, Antony,(2011), "Hypothecated Taxation". Library House of Common: Business and Transport Section. http://www.google. $\mathrm{com} / \mathrm{search}$ ? sourceid=chrome\&ie=UTF$8 \& \mathrm{q}=\% \mathrm{E} 2 \% 80 \% 9 \mathrm{CHypothecated+Taxation}$

Siahaan, Marihot Pahala, (2010), Pajak Daerah dan Retribusi Daerah. Edisi revisi, Jakarta: Rajawali pers.

Smith, Roger S. (1975), Financing Cities in Developing Countries. In Readings on Taxation in Developing Countries, ed. Richard M. Bird and Oliver Oldman, 439451. Baltimore and London: The John Hopkins University Press.

Surbakti, Christine Carolina. (2011), Peramalan Sumber-Sumber Earmarking Penerimaan Daerah (Studi Kasus: Pembiayaan Pemeliharaan Jalan Kota di Kota Bandung).Jurnal Perencanaan Wilayah dan Kota, Vol.22 No.3.

Tifany NG. (2015), "Financing From General Revenue or Earmarked Tax?". http://www. legco.gov.hk/research-publications/english/ essentials-1415ise01-financing-fromgeneral-revenue-or-earmarked-tax.htm. accessed May 10, 2017.

Wilkinson, Margaret,(1994), "Paying for Public Spending: is there a Role for Earmarked Taxes ?". Journal of Fiscal Studies Vol. 15. No. 4 pp. 119-35.

World Road Association (PIARC). (2015), Funding and financing of road infrastructure beyond the global financial crisis. August 2015. Technical Committee 1.2 - Financing.http:// www.piarc.org/es/biblioteca-virtual/6298 espricing $\% 20$ as $\% 20 \mathrm{a} \% 20$ tool $\% 20$ for $\% 20$ funding\%20and $\% 20$ regulation $\% 20 \mathrm{in} \% 20$ an\%20equity-s\%20perspective.htm 